\title{
Examining the relationship between income inequality, taxation and economic freedom: A panel cointegration approach
}

\author{
Achillefs Karakotsios ${ }^{*}$ • Constantinos Katrakilidis • \\ Dimitrios Dimitriadis • Theodoros Christoforidis
}

Aristotle University of Thessaloniki, Thessaloniki, Greece

Received: 30 December 2019

Revised: 8 April 2020

Accepted: 8 April 2020

\begin{abstract}
Income inequality has become an important challenge for both developed and developing countries. Taxation and economic freedom are considered as important factors affecting income inequality. This paper aims at the empirical investigation of the causal relationships between income inequality, taxation and economic freedom by applying panel cointegration techniques and Pooled Mean Group (PMG) estimation method on a panel of 58 countries, over the period 1995-2016. The empirical evidence supports a bidirectional long-run causal effect between taxes-to-GDP ratio and income inequality with tax-to-GDP ratio to cause negative impact on income inequality and thus revealing the redistributive role of taxes. Furthermore, we find a positive effect of the economic freedom on income inequality, suggesting a trade-off between economic freedom and income equality.
\end{abstract}

Keywords: income inequality, taxation, economic freedom, redistribution, cointegration JEL Classification Codes: C33, D31, D63, H20, H23

\section{Introduction}

Income inequality has always been an issue of great concern particularly for policy makers as well as an important challenge for both developed and developing countries. IMF (2015) argues that income inequality is negatively associated with economic growth. Furthermore, high levels of income inequality can result in large social costs, affecting educational and occupational choices. Also, Bampinas et al. (2017) document a negative effect of income inequality on consumption in the long run. However, IMF (2015) supports that some degree of inequality is welcomed, since complete equality may distort the incentives for competition, saving, investment and innovation.

\footnotetext{
*Corresponding author. E-mail: akarakots@econ.auth.gr.

Citation: Karakotsios, A., Katrakilidis, C., Dimitriadis, D., and Christoforidis, T. (2020) Examining the relationship between income inequality, taxation and economic freedom: A panel cointegration approach, Economics and Business Letters, 9(3), 206-215.
}

DOI: 10.17811/ebl.9.3.2020.206-215 
Since tax policy is considered as an important factor affecting income inequality due to distributive effects on income, mobilizing taxes by policy makers could be among the key-policies in tackling income inequality.

Furthermore, income inequality is linked to the economic reform policies followed by many countries and the rushed manner in which these policies have been carried out (Cornia and Court, 2001).

Prior literature concentrates on the empirical investigation of the relationships between taxation and income inequality and economic freedom and income inequality. The debate over the role of taxation and economic freedom on income inequality is diversified and the relevant empirical research could be categorized into two strands: the first one focuses on the relationship between taxation and income inequality, while the second one on the nexus between economic freedom and income inequality.

On the relationship between income inequality and taxation, most of the empirical studies concentrate on the impact of the tax structure or tax progressiveness on income inequality as measured by different inequality indices. There is a broad consensus among empirical researchers that taxation has a negative effect on income inequality (Clark and Lawson, 2008; Nantob, 2016; Drucker et al., 2017; Iosifidi and Mylonidis, 2017; OECD, 2017; Martinez-Vazquez et al., 2012; Martorano, 2018). Different econometric methods are used to capture the effect of taxes on income inequality (OLS, FE, 2SLS, IV, GMM). Taxation is considered as an important policy instrument not only for reducing income inequality, but also to raise public revenue, to provide incentives for investment and to correct market failures (Prasad, 2008). Moreover, taxes can serve to stabilize economy by following counter-cyclic policies, to allocate by providing public goods and to distribute income by reducing income inequality (Musgrave, 1959). The effect of taxes on income inequality is closely associated to fund spending. As a result, larger governments are expected to reduce inequality more (OECD, 2017). There is also a limited number of empirical studies that examine the reverse direction of the possible effect (Adam et al., 2015; Islam et al., 2018; Aizenman and Jinjarak, 2012). According to this channel, high levels of income inequality are expected to cause more fiscal redistribution and as a result, to create a disincentive to work and invest.

The second strand of research comprises numerous studies that examine the relationship between economic freedom and income inequality. It is argued that economic freedom affects income inequality in different ways (Carter, 2007; Apergis et al., 2013). First, it widens the opportunities to earn income by removing legal barriers and giving equal access to property rights. As a result, economic freedom is expected to reduce income inequality. Second, economic freedom is also considered to have a positive effect on income inequality, since it means more liberalized policies using the channel of non-progressive taxes, spending and regulatory framework. This, in turn, limits redistribution in favor of high incomes. Finally, economic freedom is assumed to impact income distribution by promoting economic growth. In the first stages of economic growth, economic freedom is expected to raise income inequality; hence, as the economy reaches high levels of development, income inequality lowers. Empirical research on the relationship between economic freedom and income inequality has produced mixed results. Different results can be attributed to the differences on period, dataset of countries or econometric methodology. Numerous empirical studies support the existence of a negative relationship between income inequality and economic freedom (Berggren, 1999; Scully, 2002; Clark and Lawson, 2008; Apergis and Cooray, 2015). By contrast, there is also empirical research in favor of a tradeoff between economic freedom and income inequality. Carter (2007) and Bergh and Nilsson (2010) find that economic freedom is positively associated with income inequality. Finally, there are empirical studies that report evidence of bidirectional causality between the aforementioned variables (Apergis et al., 2013) or of no effect at all (Sturm and De Haan, 2015). 
This paper aims at determining the role of tax and liberalization policies on income inequality through the investigation of the dynamic linkages between taxation, income inequality and economic freedom using panel cointegration for a sample of 58 countries and over the period 19952016. Our effort aims to bridge the two strands of the literature under a tri-dimensional panel cointegration framework. This would allow us to explore potential causal relationships between income inequality, taxation and economic freedom and to reach important conclusions for policy designation in order to reduce income inequality.

More specifically, this paper contributes to the existing literature in three ways: first, it attempts to examine the dynamic linkages between taxation and income inequality within a trivariable framework. Economic freedom is added as a proxy for country-specific institutional settings. IMF (2015) supports the idea that there is no one-size-fits-all approach to reducing inequality and consequently policy designation should take into account country-specific characteristics and institutional settings. Second, it applies the panel cointegration approach, and in specific the PMG estimator, in order to examine possible causal relationships, both in the long and the short-run time horizon and in a global context. Through this approach, we are able to focus not only on the redistributive impact of tax policy but also on the potential reverse causation between taxation and income inequality. The advantage of the PMG estimator, proposed by Pesaran, Shin, and Smith (1999), compared to other panel estimators (i.e. fixed effects) is that it allows short-run coefficients, including the intercepts, the speed of adjustment to the long run equilibrium values, and error variances to differ across cross-sections (countries) while it is based on the assumption of a same long-run coefficient across countries by pooling the data. Third, the obtained evidence offers valuable information for policy designation.

Our findings support the existence of bidirectional long-run causal effects between taxes-to$G D P$ ratio and income inequality. The results further indicate that economic freedom has a positive long-run effect on income inequality, confirming a trade-off between economic freedom and income equality.

The article is structured as follows. Section 2 outlines our econometric methodology and section 3 provides the data set and the results of the empirical analysis. Conclusions and policy implications are presented in the last section.

\section{Methods}

The first step of our analysis is to test for the integration properties of the variables in question. Evidence that the variables follow a stationary process is essential when examining the existence of a cointegration relationship. For this reason, we employ five panel unit root tests to examine the null hypothesis that all panels contain unit roots: Levin, Lin and Chu (2002), Breitung (2001), Im, Pesaran and Shin (2003) and Fisher-ADF and Fisher-PP (Maddala and Wu, 1999). The Levin, Lin, and Chu (LLC) and Breitung tests employ the assumption that the persistence parameters are common across cross-sections. On the contrary the Im, Pesaran, and Shin (IPS), and Fisher-ADF and Fisher-PP tests allow the autoregressive coefficients to vary freely across cross-sections. All the tests employ the null hypothesis that there is a unit root while the alternative hypothesis is the absence of a unit root.

In the second stage, we apply two different methods to test for the existence of long term equilibrium among the variables included in the model. The Pedroni $(1999,2004)$ panel cointegration test and the Kao (1999) test. The Pedroni $(1999,2004)$ test allows for heterogeneous intercepts and trend coefficients across cross-sections. Under the null hypothesis of no cointegration, the specific test examines two alternative hypotheses: homogeneity for all cross sections referred to as the within-dimension test or panel statistics test), and heterogeneity for all cross sections (referred to as the between-dimension or group statistics test). The Kao (1999) 
test follows the same basic approach as the Pedroni (1999, 2004), but assumes homogeneity across panels.

Once the variables are found to be cointegrated, the next step is to determine the long-run and short-run dynamics estimators by employing the panel Autoregressive Distributed Lag (ARDL) model.

We assume that the long-run inequality-taxes relationship follows the specification below, where countries are represented by $i$ and time by $t$. Following the cointegration approach, our model takes the forms as specified below:

$$
\begin{aligned}
\operatorname{gini}_{i t} & =a_{0 i}+a_{1 i} \operatorname{tax}_{i t}+a_{2 i} e f_{i t}+u_{i t} \\
\operatorname{tax}_{i t} & =\beta_{0 i}+\beta \text { gini }_{i t}+\beta_{2 i} e f_{i t}+e_{i t}
\end{aligned}
$$

Accordingly, the ARDL error correction models take the form:

$$
\begin{gathered}
\Delta \operatorname{gini}_{i, t}=\lambda_{i} E C T_{i, t}+\sum_{j=0}^{q-1} \Delta \operatorname{tax}_{i, t-j^{\prime}} \beta_{i, j}+\sum_{j=0}^{q-1} \Delta e f_{i, t-j^{\prime}} \gamma_{i, j}+\sum_{j=1}^{p-1} \delta_{i, j} * \Delta \operatorname{gini}_{i, t-j} \\
\Delta \operatorname{tax}_{i, t}=\lambda_{i} E C T_{i, t}+\sum_{j=0}^{q-1} \Delta \operatorname{gini}_{i, t-j^{\prime}} \beta_{i, j}+\sum_{j=0}^{q-1} \Delta e f_{i, t-j^{\prime}} \gamma_{i, j}+\sum_{j=1}^{p-1} \delta_{i, j} * \Delta \operatorname{tax}_{i, t} .
\end{gathered}
$$

where gini is the index of income inequality, tax is the taxes-to-GDP ratio, ef is the respective index of economic freedom and $u_{i t}$ and $e_{i t}$ are normally distributed errors terms. Also, ect stands for the error correction term. We expect that the parameter $\lambda$ which is the speed of adjustment to a long-run equilibrium, to be statistically significant and negative, documenting the presence of a long-run cointegration relationship between our variables.

The mean group (MG) and pooled mean group (PMG) estimators are used to estimate large panel data models of form (3). The PMG estimator, proposed by Pesaran, Shin, and Smith (1999) is based on the assumption of a same long-run coefficient across countries by pooling the data, but allows the intercepts, short-run coefficients and error variances to differ across countries. On the contrary, the MG estimator, proposed by Pesaran and Smith (1995) allows the intercepts, sloped coefficients and error variances to differ across countries without pooling the data, since the model is estimated separately for each individual cross section, and the coefficients are provided as arithmetic averages. Next, the standard Hausman (1978) test is employed to determine the appropriate model.

\section{Data}

The most widely used income inequality measure is the Gini coefficient. This analysis employs the estimate of Gini index of household disposable (post-tax, post-transfer) income. The Gini index ranges from 0 (complete equality, all households receive the same income) to 100 (complete inequality, one household receives all income). Data for income inequality were obtained from the Standardized World Income Inequality Database (SWIID Version 7.1) (Solt, 2016). The data set combines a number of different sources: OECD Income Distribution Database, Economic Database for Latin America and the Caribbean generated by CEDLAS and the World Bank, Eurostat, World Bank, UN, national statistical offices and other sources.

As for taxation, we use as a proxy the taxes-to-GDP ratio collected from the International Centre for Tax and Development (ICTD) Government Revenue Dataset (GRD) (Prichard et al. 2014). The total tax revenue, including social contributions as a percentage of GDP was selected in order to construct the taxes-to-GDP ratio.

The index of economic freedom (Heritage Foundation, 2019) as a variable capturing the country specific institutional setting was further selected to investigate the potential differential effect of liberalization policies on the nexus between taxation and income inequality. 
Table 1. Data description.

\begin{tabular}{llll}
\hline \hline Variable & Abbreviation & Description & Source \\
\hline Gini index & gini & $\begin{array}{l}\text { Estimate of Gini index of ine- } \\
\text { quality in household disposa- } \\
\text { ble income }\end{array}$ & $\begin{array}{l}\text { Standardized World } \\
\text { Income Inequality Da- } \\
\text { tabase }\end{array}$ \\
Tax to GDP ratio & tax & $\begin{array}{l}\text { Total tax revenue including so- } \\
\text { cial contributions as a percent- } \\
\text { age of GDP }\end{array}$ & $\begin{array}{l}\text { International Centre } \\
\text { for Tax and Develop- } \\
\text { ment }\end{array}$ \\
Economic freedom & Index of economic freedom & $\begin{array}{l}\text { The Heritage Founda- } \\
\text { tion }\end{array}$ \\
\hline \hline
\end{tabular}

Note: All the series were converted into logarithms.

Our panel dataset consists of 58 countries over the period of 1995-2016, with a total of 1276 annual observations. The Appendix A lists the 58 countries included in the analysis. Table 1 provides the abbreviations and brief descriptions of the variables used.

\section{Results}

Table 2 reports the findings from the applied panel unit root tests.

The results suggest that all the examined variables are integrated of order one, $I(1)$, that is they are nonstationary in levels but they all turn stationary in first differences. Consequently, since they are found nonstationary of the same order of integration we can proceed with testing for the existence of a possible long-run cointegration relationship.

The results of the Pedroni $(1999,2004)$ and Kao (199) panel cointegration tests are illustrated in Table 3. The null hypothesis of no cointegration is rejected for the majority of the tests.

According to the results reported in Table 4, we accept the null hypothesis that the PMG estimator is more consistent and efficient estimator.

Table 2. Panel unit root test results.

\begin{tabular}{lrrrrrrr}
\hline \hline & & \multicolumn{2}{c}{ Level } & & \multicolumn{3}{c}{ First Difference } \\
\hline Test & lgini & ltax & lef & lgini & ltax & lef \\
\hline \multirow{2}{*}{ LLC } & $\mathbf{- 1 . 3 6 0 7 5}$ & 0.62244 & $\mathbf{- 1 . 6 7 2 5 1}$ & $\mathbf{- 5 . 1 5 4 4 9}$ & $\mathbf{- 1 8 . 7 8 4 1}$ & $\mathbf{- 2 0 . 2 9 7 4}$ \\
& $(0.0868)$ & $(0.7332)$ & $(0.0472)$ & $(0.0000)$ & $(0.0000)$ & $(0.0000)$ \\
\multirow{2}{*}{ BR } & 7.07259 & 1.95435 & 1.19346 & $\mathbf{- 1 . 5 1 8 2 6}$ & $\mathbf{- 1 2 . 0 7 5 6}$ & $\mathbf{- 1 1 . 3 7 0 2}$ \\
& $(1.0000)$ & $(0.9747)$ & $(0.8837)$ & $(0.0645)$ & $(0.0000)$ & $(0.0000)$ \\
\multirow{2}{*}{ IPS } & 4.06426 & 2.11047 & 0.33341 & $\mathbf{- 3 . 8 8 2 7 6}$ & $\mathbf{- 1 4 . 4 0 2 3}$ & $\mathbf{- 1 5 . 6 3 5 3}$ \\
& $(1.0000)$ & $(0.9826)$ & $(0.6306)$ & $(0.0001)$ & $(0.0000)$ & $(0.0000)$ \\
\multirow{2}{*}{ ADF-F } & 83.0536 & 83.3823 & 128.523 & $\mathbf{2 0 2 . 6 5 6}$ & $\mathbf{3 9 5 . 2 7 5}$ & $\mathbf{4 5 3 . 3 1 7}$ \\
& $(0.9910)$ & $(0.9903)$ & $(0.2011)$ & $(0.0000)$ & $(0.0000)$ & $(0.0000)$ \\
\multirow{2}{*}{ PP-F } & 90.3722 & 114.842 & 134.705 & $\mathbf{3 3 6 . 0 4 3}$ & $\mathbf{5 3 4 . 4 3 6}$ & $\mathbf{9 3 0 . 3 6 7}$ \\
& $(0.9625)$ & $(0.5129)$ & $(0.1130)$ & $(0.0000)$ & $(0.0000)$ & $(0.0000)$ \\
\hline \hline
\end{tabular}

Note: (LLC) - Levin, Lin \& Chu test, (BR) - Breitung Test, (IPS) - Im, Pesaran, and Shin test, (ADF-F) - ADF Fisher, PP-F-PP Fisher. SIC used for the optimal lag length (0-2). All tests use as Ho the existence of a unit-root. Values in parentheses are p-values. 
Table 3. Panel Cointegration Test Results.

\begin{tabular}{|c|c|c|c|c|}
\hline \multicolumn{5}{|c|}{ Pedroni Residual Cointegration Test } \\
\hline \multicolumn{5}{|c|}{ Alternative hypothesis: common AR coefs. (within-dimension) } \\
\hline & Statistic & p-value & $\begin{array}{r}\text { Weighted } \\
\text { Statistic }\end{array}$ & p-value \\
\hline Panel v-Statistic & -4.474545 & 1.0000 & -5.395480 & 1.0000 \\
\hline Panel rho-Statistic & 0.250508 & 0.5989 & -0.970197 & 0.1660 \\
\hline Panel PP-Statistic & -2.710175 & 0.0034 & -4.326234 & 0.0000 \\
\hline Panel ADF-Statistic & -2.760913 & 0.0029 & -6.568010 & 0.0000 \\
\hline \multicolumn{5}{|c|}{ Alternative hypothesis: individual AR coefs. (between-dimension) } \\
\hline & Statistic & p-value & & \\
\hline Group rho-Statistic & 2.154608 & 0.9844 & & \\
\hline Group PP-Statistic & -2.434728 & 0.0075 & & \\
\hline Group ADF-Statistic & $-\mathbf{3 . 5 8 7 7 8 1}$ & 0.0002 & & \\
\hline \multicolumn{5}{|c|}{ Kao Residual Cointegration Test } \\
\hline $\mathrm{ADF}$ & $\begin{array}{r}\text { Statistic } \\
-\mathbf{1 . 7 9 8 2 6 1}\end{array}$ & $\begin{array}{r}\text { p-value } \\
0.0361\end{array}$ & & \\
\hline
\end{tabular}

Note: Null hypothesis: no cointegration.

Table 4. Model Selection.

Hausman Test for model selection

\begin{tabular}{cccr}
\hline Null Hypothesis (Ho) & $\begin{array}{c}\text { Alternative Hypothesis } \\
\text { (Ha) }\end{array}$ & chi $^{2}$ & p-value \\
\hline PMG & MG & 0.55 & 0.7599 \\
\hline Ho: PMG is the consistent and efficient estimator & & \\
\hline \hline
\end{tabular}

Suggestion: PMG.

Table 5 provides the estimates of the long and short-run parameters of the model having as dependent variable the gini index. The error correction term ect is found negative and statistically significant providing evidence of a long-run cointegration relationship between our variables. The speed of adjustment to the long run equilibrium is estimated to 5\% per year. The results suggest that there is a long-run negative causal effect running from taxes to income inequality. On the contrary, they support a long-run positive causal effect running from economic freedom to income inequality. In the short-run horizon, a weak causal effect running from taxes to income inequality is found, while there is no evidence for causality running from economic freedom to income inequality.

Table 5. Summary of the panel regression model - Dependent variable gini.

\begin{tabular}{|c|c|c|}
\hline \multicolumn{3}{|c|}{ Dependent variable gini } \\
\hline \multicolumn{3}{|c|}{ Panel PMG } \\
\hline Variables & Coefficient & P-value \\
\hline \multicolumn{3}{|l|}{ Long-run } \\
\hline $\operatorname{tax}$ & -0.5094 & $(0.000)$ \\
\hline ef & 0.4700 & $(0.000)$ \\
\hline \multicolumn{3}{|l|}{ Short-run } \\
\hline ect & -0.0522 & $(0.001)$ \\
\hline$\Delta \operatorname{tax}$ & $\mathbf{0 . 0 2 2 7}$ & $(0.056)$ \\
\hline$\Delta e f$ & -0.0167 & $(0.220)$ \\
\hline constant & 0.1654 & $(0.002)$ \\
\hline
\end{tabular}

Note: ect stands for the Error Correction Term. 
Table 6. Summary of the panel regression model - Dependent variable tax.

\begin{tabular}{lrr}
\hline \hline \multicolumn{3}{c}{ Dependent variable tax } \\
\hline \multicolumn{3}{c}{ Panel PMG } \\
\hline Variables & Coefficient & P-value \\
\hline Long-run & & \\
gini & $\mathbf{- 0 . 1 7 6 7}$ & $(0.004)$ \\
f & -0.0179 & $(0.708)$ \\
Short-run & & \\
ect & & $(0.000)$ \\
Agini & $\mathbf{- 0 . 2 6 7 0}$ & $(0.543)$ \\
Sef & -0.3870 & $(0.804)$ \\
constant & -0.0205 & $(0.000)$ \\
\hline \hline
\end{tabular}

Note: ect stands for the Error Correction Term.

Table 7. Direction of Causality.

\begin{tabular}{lll}
\hline \hline Direction of Causality & Long-run & Short-run \\
\hline taxes $\rightarrow$ inequality & Yes $(-)$ & Yes $(+)^{*}$ \\
economic freedom $\rightarrow$ inequality & Yes $(+)$ & No \\
inequality $\rightarrow$ taxes & Yes $(-)$ & No \\
economic freedom $\rightarrow$ taxes & No & No \\
\hline \hline
\end{tabular}

*weak evidence

Table 6 presents the estimates of the long and short-run parameters of the model having as dependent variable the $t a x-t o-g d p$ ratio. The error correction term ect is also found negative and statistically significant documenting the presence of a long-run cointegration relationship between our variables. The speed of adjustment to the long run equilibrium is estimated to $26.7 \%$ per year. The results suggest that there is a long-run negative causal effect running from income inequality to the tax-to-gdp ratio. However, we find no evidence of long-run causal effect running from lef to ltax or short-run effects.

Table 7 provides a summary of the directions of causality evidenced in this empirical research. The results of the Pooled Mean Group (Panel ARDL) estimation support the existence of a bidirectional long-run causal effect between taxes-to-GDP ratio and income inequality. In particular, our empirical findings reveal a negative impact of taxes on income inequality, in line with the majority of the relevant empirical studies. There is also evidence of negative feedback effects. The estimated long-run coefficients on ltax and lgini are -0.50 and -0.17 respectively. Therefore, we may conclude that a $1 \%$ increase in taxes results in a $0.50 \%$ fall in income inequality. Similarly, a $1 \%$ increase in the gini index leads to a $0.17 \%$ decrease in tax-to-GDP ratio. Economic freedom is found to have a significant positive effect on income inequality a finding consistent with the results of certain previous empirical studies (Carter, 2007; Bergh and Nilsson, 2010).

\section{Concluding remarks}

This paper has empirically investigated the causal relationship between taxation, income inequality and economic freedom for 58 countries within a tri-variate cointegration panel framework, over the period 1995-2016. Our analysis aimed at determining the role of tax and liberalization policies on income inequality, since they are considered as key-policy instruments in affecting income inequality.

Our findings support the existence of a bidirectional long-run causal effect between taxes-toGDP ratio and income inequality. The negative effect of tax-to-GDP ratio on income inequality 
supports the redistributive role of taxes. It can be argued that taxation can be an important policy instrument for reducing inequality. However, it remains difficult to provide policy recommendations when using the tax instrument for redistributive purposes. It is crucial that taxes should not become disincentives to work and invest. Policy makers should therefore take into account possible consequences on employment and growth

On the other hand, the negative impact of income inequality on taxes can be attributed to that inequality might encourage tax avoidance and tax evasion resulting in low levels of tax-compliance. As a consequence, high levels of income inequality are followed by increased tax revenues as a percentage of GDP.

Our findings further suggest that economic freedom has a positive effect on income inequality, revealing a trade-off between economic freedom and income equality. In other words, institutional changes and liberalization policies have important implications in terms of income distribution and inequality.

Better understanding of the linkages between income inequality, taxation and economic freedom could help to formulate and implement tax and liberalization policies that carefully balance the goal of a moderate level of income inequality with growth and employment rates preservation.

\section{References}

Adam, A., Kammas, P. and Lapatinas, A. (2015) Income inequality and the tax structure: Evidence from developed and developing countries, Journal of Comparative Economics, 43(1), 138-154.

Aizenman, J. and Jinjarak, Y. (2012) Income inequality, tax base and sovereign spreads, Working Paper 18176, National Bureau of Economic Research.

Apergis, N. and Cooray, A. (2015) Economic Freedom and Income Inequality: Evidence from a Panel of Global Economies- A Linear and a Non-Linear Long-Run Analysis, The Manchester School, n/a-n/a. 10.1111/manc.12137.

Apergis, N., Dincer, O. and Payne, J.E. (2013) Economic Freedom and Income Inequality revisited: Evidence form a panel error correction model, Contemporary Economic Policy, 32(1), 67-75.

Bampinas, G., Konstantinou, P., and Panagiotidis, T. (2017) Inequality, demographics and the housing wealth effect: Panel quantile regression evidence for the US, Finance Research Letters, 23, 19-22.

Berggren, N. (1999) Economic freedom and equality: friends or foes? Public Choice, 100(3-4), 203-223.

Bergh A. and Nilsson, T. (2010) Do liberalization and globalization increase income inequality? European Journal of Political Economy, 26(4), 488-505.

Breitung, J. (2001) The local power of some unit root tests for panel data. In Baltagi, B., Fomby, T. and Carter Hill, R. (Ed.) Nonstationary Panels, Panel Cointegration, and Dynamic Panels (Advances in Econometrics, Vol. 15). Emerald Group Publishing Limited: Bingley, 161-177.

Carter, J.R. (2007) An empirical note on economic freedom and income Inequality, Public Choice, 130(1), 163-177.

Clark, J.R. and Lawson, R.A. (2008) The impact of economic growth, tax policy and economic freedom on income inequality, Journal of Private Enterprise, 24(1), 23-31.

Cornia, G.A. and Court, J. (2001) Inequality, Growth and Poverty in the Era of Liberalization and Globalization, UNU World Institute for Development Economics Research (UNU/WIDER), UNU-WIDER Policy Brief, Volume 4/2001. 
Drucker, L., Krill, Z. and Geva, A. (2017) The Impact of Tax Composition on Income Inequality and Economic Growth, available at: https://www.mof.gov.il/en/PublicationsAndReviews/EconomicData/DocLib/Article_082017_Eng.pdf

Hausman, J. A. (1978) Specification Tests in Econometrics, Econometrica, 46(6), 1251-1272.

Heritage Foundation (2019) The Index of Economic Freedom, available at: https://www.heritage.org/index/

IMF (2015) Causes and Consequences of Income Inequality: A Global Perspective, Strategy, Policy and Review Department, IMF Staff Discussion Note, SDN/15/13.

Im, K. S., Pesaran, M. H. and Shin, Y. (2000) Testing for Unit Roots in Heterogeneous Panels, Journal of Econometrics, 115(1), 53-74.

Iosifidi, M. and Mylonidis, N. (2017) Relative effective taxation and income inequality: Evidence from OECD countries, Journal of European Social Policy, 27(1), 57-76.

Islam, Md.R. Madsen, J.B. and Doucouliagos, H. (2018) Does inequality constrain the power to tax? Evidence from the OECD, European Journal of Political Economy, 52(C), 1-17.

Kao, C. (1999) Spurious regression and residual-based tests for cointegration in panel data, Journal of Econometrics, 90(1), 1-44.

Levin, A., Lin, C.F., and Chu, C. (2002) Unit Root Tests in Panel Data: Asymptotic and FiniteSample Properties, Journal of Econometrics, 108(1), 1-24.

Maddala, G.S. and Wu, S. (1999) A Comparative Study of Unit Root Tests with Panel Data and a New Simple Test, Oxford Bulletin of Economics and Statistics, 61, 631-652.

Martinez-Vazquez, J., Vulovic, V. and Moreno-Dodson, B. (2012) The Impact of Tax and Expenditure Policies on Income Distribution: Evidence from a Large Panel of Countries, Hacienda Publica Espanola, 200(1), 95-130.

Martorano, B. (2018) Taxation and Inequality in Developing Countries: Lessons from the Recent Experience of Latin America, Journal of International Development, 30(2), 256-273.

Musgrave, R. A. (1959) The theory of public finance, McGraw-Hill: New York.

Nantob, N. (2016) Taxation and Income Inequality in Developing Countries: An Empirical Investigation, Economics Bulletin, Access Econ, 36(3), 1508-1522.

OECD (2017) The effects of the tax mix on inequality and growth, OECD Economics Department Working Papers No. 1447.

Pedroni, P. (1999) Critical Values for Cointegration Tests in Heterogeneous Panels with Multiple Regressors, Oxford Bulletin of Economics and Statistics, 61, 653-70.

Pedroni, P. (2004) Panel Cointegration: Asymptotic and Finite Sample Properties of Pooled Time Series Tests with an Application to the PPP Hypothesis, Econometric Theory, 20(3), 597-625.

Pesaran, M. and Smith, R. (1995) Estimating long-run relationships from dynamic heterogeneous panels, Journal of Econometrics, 68(1), pp.79-113.

Pesaran, M., Shin, Y. and Smith, R. (1999) Pooled Mean Group Estimation of Dynamic Heterogeneous Panels, Journal of the American Statistical Association, 94(446), 621-634.

Prasad, N. (2008) Policies for Redistribution: The Use of Taxes and Social Transfers, International Institute for Labour Studies, Discussion Paper 194, available at SSRN: https://ssrn.com/abstract=1358237.

Prichard, W., Goodall, A. and Cobham, A. (2014) The ICTD Government Revenue Dataset, ICTD Working Paper 19, Brighton: International Centre for Tax and Development.

Scully, G.W. (2002) Economic freedom, government policy and the trade-off between equity and economic growth, Public Choice, 113(1-2), 77-96.

Solt, F. (2016) The Standardized World Income Inequality Database, Social Science Quarterly 97, SWIID Version 7.1, August 2018.

Sturm, J-E. and De Haan, J. (2015) Income inequality, capitalism, and ethno-linguistic fractionalization, American Economic Review, 105(5), 593-597. 


\section{Appendix A $\mathbf{- 5 8}$ country panel}

Armenia, Australia, Austria, Bangladesh, Belgium, Brazil, Bulgaria, Canada, Costa Rica, Croatia, Cyprus, Czech Republic, Denmark, Dominican Republic, Ecuador, El Salvador, Estonia, Finland, France, Germany, Greece, Guatemala, Honduras, Hong Kong SAR China, Hungary, Iceland, Ireland, Israel, Italy, Japan, Jordan, Korea, Rep., Latvia, Lithuania, Luxembourg, Moldova, Mongolia, Netherlands, New Zealand, Norway, Panama, Paraguay, Peru, Philippines, Poland, Portugal, Slovak Republic, Slovenia, Spain, Sweden, Switzerland, Turkey, Ukraine, United Kingdom, United States, Uruguay, Venezuela, Vietnam. 